\title{
Research Related to Capsular Contracture after Breast Augmentation for Cosmetic or Reconstructive Purposes
}

\author{
SILVIU ADRIAN MARINESCU1, DAN MIRCEA ENESCU², CATALIN GHEORGHE BEJINARIU ${ }^{1 *}$, CARMEN GIUGLEA ${ }^{3}$ \\ ${ }^{1}$ Bagdasar-Arseni Emergency Clinical Hospital, Department of Plastic and Reconstructive Surgery, 12 Soseaua Berceni, 041915, \\ Bucharest, Romania \\ ${ }^{2}$ Grigore Alexandrescu Emergency Clinical Hospital, Depatment of Plastic and Reconstructive Surgery, 30-32 lancu de Hunedoara \\ Blvd., 011743, Bucharest, Romania \\ ${ }^{3}$ Saint John Emergency Clinical Hospital, Department of Plastic and Reconstructive Surgery, 13 Soseaua Vitan-Barzesti 13, \\ 042122, Bucharest, Romania
}

\begin{abstract}
The upward trend of patients opting for elective breast augmentation, as well as the large number of patients benefiting from alloplastic breast reconstruction, require further studies on the safety profile of these techniques. Without any doubt, the incidence of Breast Implant-Associated Anaplastic Large Cell Lymphoma (BIA-ALCL) has drawn attention to the possible unknown complications characteristic of these procedures, creating the context of further studies devoted to this issue. The present research examines the capsular contracture rate on a group of 253 patients between 2015 and 2019, also proposing a scoring system based on the integration of the main diagnostic criteria related to the capsular contracture. The results of the literature review indicate that a lower incidence of capsular contracture could be achieved by using the newest techniques in the field involving the application of chemical substances on the surface of the latest generation of silicone breast implants.
\end{abstract}

\section{Keywords: capsular contracture, breast augmentation, breast reconstruction, silicone breast implant}

Worldwide breast augmentation with silicone implants is one of the most demanded aesthetic surgery. In the United States, the number of breast augmentations increased by $4 \%$ in 2018 compared to 2017 and by $48 \%$ compared to 2000 . Another significant aspect is that $88 \%$ of the surgical interventions are being performed using silicone breast implants rather than saline prostheses [1]. Regarding breast implant removals, the statistical data shows that there were $28 \%$ less surgeries in 2018 compated to the year 2000, a significant contribution to this improvement being brought by the quality of the new generations of breast implants. Also, the use of silicone implants for breast reconstruction [2,3] shows an upward trend, the main reasons being the relatively easy surgical technique and the patients' preference for this type of implant. However, the American statistics show that the total number of reconstructive interventions in the mammary region declined by $4 \%$ in 2018 compared to 2017, a trend that can also be attributed to the relatively recent identification of BIA-ALCL [4]. In light of the above, it is easy to understand why the scientific community dedicated to the understanding of the physiopathological processes related to breast augmentation is concerned with the safety of these implants and is actively searching for new methods of improving their structural elements. The issue of BIA-ALCL is a controversed topic that has attracted the international scientific community's attention to the safety features of different types of implants [5], contributing to the acceleration of centralized reporting processes related to new cases at international level, as well as changing the protocols and production profiles of the new generations of silicone prostheses. Without a doubt the understanding of the mechanisms involved in the physiopathological processes related to the occurence of the capsular contracture is extremely important, given the fact that the accelerated fibrosis of the capsule seems to be determined by the structure and the chemical materials used by the manufacturers.

Silicone implants have evolved since their first use in 1962 [6]. The first generation of implants had anatomical shape, smooth surface and included dacron patches designed to provide an optimal fit. The composition of the prosthesis involved silicone of moderate consistency, which is a factor that along with the implant surface characteristics have contributed to the increase in the rate of capsular contracture. The second generation of implants has conceptually introduced a much thinner coating that does not stimulate the immune response in order to reduce the rate of capsular contracture. The consequences of these changes were not the expected ones, the modification of the coating structure determining the phenomenon of silicone bleeding manifested by the exteriorization of the material in the periprosthetic space. The third generation of implants was characterized by the increased resistance of the silicone implant coating, which resulted in the reduction of complications, such as fissures, ruptures and silicone bleeding. However, the capsular contracture rate remained high, which required the improvement of the prostheses, creating the context of the appearance of the $4^{\text {th }}$ and $5^{\text {th }}$ generations of silicone prostheses, which were characterized by the improvement of the implant coating structure, the introduction of the textured surfaces [7], and the increase in the degree of cross-linking.

The introduction of the textured surface was an important development related to the silicone breast prostheses, significantly reducing the rate of the fibrotic complications such as capsular contracture. However, recent data from the literature show that this type of surface can be associated with the appearance of BIA$\mathrm{ALCL}$ [8], a factor that have led to the introduction of the micro- or nanotextured surface concept [9], which has the advantage of decreasing the capsular contracture rate by inhibiting the foreign body-type immune response [10], while reducing the risk of BIA-ALCL. Additional studies and a long-term analysis related to this relatively new type of breast implants are required in order to identify the characteristics of the relationship between this type of implant surface, the capsular contracture rate and the risks of BIA-ALCL occurrence. The specialized literature includes a variety of materials dedicated to understanding of the

* email: drbejinariu@gmail.com 
biochemical processes that contribute to the occurence of the capsular contracture. The average rate of this type of complication is between $9.5 \%$ and $11 \%$ and relates to patients who have undergone breast augmentation, textured surface implants being associated with a lower rate of this complication [11,12].

Deficiencies occurring during the classical stages of the fibrosis process influence the development of the patients' clinical picture [13]. Fibrosis is a natural process that is triggered during the interaction between the body and the environment, being caused by the following main factors: haemorrhage, infection [14], immune system response to allergens, foreign body reaction or neoplasm [15].

The increased incidence of the conditions determined by the exacerbation of the fibrosis processes is determined by the accelerated development of implantology in all medical fields [16], but especially in breast augmentation and reconstruction. The fibrosis process occurs naturally in all patients, but its intensity appears to be influenced by the immunological profile and the biochemical features of the prosthetic material [17]. The fibrosis process starts with the interaction between the blood and the implanted material, the chemical stability of the prosthesis contributing to the reduction of this interaction's intensity. Under the influence of the chemicals on the surface of the implant, blood cells are stimulated to produce mediators meant to isolate foreign material. In the next stage the prosthesis is covered with a 2 to $5 \mathrm{~nm}$ protein layer, which is the substrate for the formation of a provisional matrix that will act as the foundation of the future implant capsule. The process described by Vroman continues with the accumulation of albumin around the newly formed structures, the protein being gradually replaced by fibrinogen, kininogen and fibronectin [18]. The temporary matrix undergoes transformation processes in the direction of progressively replacing fibrinogen with fibrin, and accumulating mediators involved in accelerating the inflammatory response. The second aspect is facilitated by the chemotactic characteristics of the alpha integrin present at this level [19].

Acute inflammation begins shortly after the insertion of the prosthetic material and is characterized by an increased activity of neutrophils and eosinophils which, through interleukins, TNF- $\alpha$ [20] and IFN Y, cause the activation of cells involved in the fibrosis process. In addition to the ability to trigger fibrosis by releasing cytokines, neutrophils also contribute to this process by forming matrix metalloproteinases, elastase and cathepsin. Also, the inflammatory response is stimulated by histamine, IL-4 and IL-13 released by mast cells, as well as by IL-8, a process that culminates by attracting a large number of leukocytes and macrophages to the interface between the implant and the tissue.

Chronic inflammation is characterized by the acceleration of the chemotaxis for macrophages and the appearance of foreign-body giant cells. In this stage, dominant cytokines are those that induce the synthesis of collagen, disfavoring the platelet-derived growth factor (PDGF) and the vascular endothelial growth factor (VEGF) $[21,22]$. This stage is associated with the formation of granulation tissue around the prosthetic material under the influence of the previously presented cytokines [23].

The fibrosis process continues with a foreign body reaction characterized by the activation of cells involved in the synthesis of collagen. This stage is therefore characterized by the increased activity of fibroblasts, miofibroblasts and foreign-body giant cells. The latter have
CD11, CD45 and CD31 proteins on the surface of their membrane, as well as other receptors involved in the transmission of intercellular messages that are able to bind to IL-1, IL-2, IL-4 and IL-8. The severity of the fibrosis process appears to be influenced by the particularities of the macrophages in the sense of modulating the inflammatory response through the following specific membrane receptors: IL-10, TGF- $\beta$, IL-1 $\alpha$, IL-6, IL-8 and TNF- $\alpha-[24]$.

The formation of the implant capsule is based on its isolation through a collagen type III network which is subsequently replaced by collagen type I, the primary consequence of this step being to disrupt the stimulation of the immune system through the chemical materials present in the prosthesis. Type 2 macrophages are those that, through PDGF, VEGF and TGF- $\beta$, stimulate the synthesis of collagen, a process that reduces its intensity when the prosthetic material is completely isolated. The failure to achieve a complete capsule results in maintaining the stimulation through cytokines, as well as through the cells involved in modulation of the immune response, thus causing the fibrosis process to continue with the occurence of clinical manifestations.

In light of the presented material, the chemical and physical characteristics of the implant coating are extremely important for the postoperative evolution of the patients. In this respect, for a long time the manufacturers of silicone prosthetic materials have offered two variants: smooth implants and textured ones. Smooth implants had the great advantage of achieving good aesthetic results, but associated with an increased rate of fibrotic complications $[25,26]$. Although the capsular contracture rate was found to be much lower in case of textured implants, the relatively recent identification of BIA-ALCL has created the context of introducing a new type of implant coating surface. Therefore, the micro- or nanotextured surface aims to reduce the risk of developing capsular contracture, while also lowering the risk of BIAALCL.

\section{Experimental part}

\section{Materials and methods}

The research was conducted based on 253 patients that have undergone breast augmentation surgery between 2007 and 2013 for both aeshtetic and reconstruction purpuses. Between 2015 and 2019 a number of 27 patients came in for surgical consults complaining about breast pain, firmness and deformity. The plastic surgeons diagnosed these patients with capsular contracture, each of the patients being asked to rate their pain on a scale of 1 to 10 . In order to determine the severity of the condition, the physician has rated the other 2 symptoms (breast firmness and deformity) using the same scale. Based on the data gathered during the consults, an evaluation matrix was developed in order to calculate a score that expresses the severity of the capsular contracture based on the 3 symptoms as evaluation criteria (PFD score) (table 1).

The proposed scoring system is based on multiplying each of the values assigned to the patients' symptoms during the surgical consult. Following, the capsular contracture severity was determined using the American Society of Plastic Surgeons grading system [27] in relation with the proposed PFD score (table 2).

In order to have a complete overview related to the patients' status, the research has gathered data related to the breast augmentation procedure, as well as demographic data and the complete medical history. 
Table 1

PROPOSED CAPSULAR CONTRACTURE PFD SCORE DEPENDING ON BREAST FIRMNESS, BREAST DEFORMITY AND BREAST PAIN

\begin{tabular}{|c|c|c|c|c|c|c|c|c|c|c|c|}
\hline 10 & \multirow{10}{*}{ 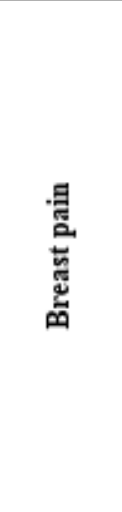 } & 10 & 40 & 90 & 160 & 250 & 360 & 490 & 640 & 810 & 1000 \\
\hline 9 & & 9 & 36 & 81 & 144 & 225 & 324 & 441 & 576 & 729 & 900 \\
\hline 8 & & 8 & 32 & 72 & 128 & 200 & 288 & 392 & 512 & 648 & 800 \\
\hline 7 & & 7 & 28 & 63 & 112 & 175 & 252 & 343 & 448 & 567 & 700 \\
\hline 6 & & 6 & 24 & 54 & 96 & 150 & 216 & 294 & 384 & 486 & 600 \\
\hline 5 & & 5 & 20 & 45 & 80 & 125 & 180 & 245 & 320 & 405 & 500 \\
\hline 4 & & 4 & 16 & 36 & 64 & 100 & 144 & 196 & 256 & 324 & 400 \\
\hline 3 & & 3 & 12 & 27 & 48 & 75 & 108 & 147 & 192 & 243 & 300 \\
\hline 2 & & 2 & 8 & 18 & 32 & 50 & 72 & 98 & 128 & 162 & 200 \\
\hline 1 & & 1 & 4 & 9 & 16 & 25 & 36 & 49 & 64 & 81 & 100 \\
\hline 0 & Criteria & \multicolumn{10}{|c|}{ Breast firmness $x$ breast deformity } \\
\hline Score & 0 & 1 & 4 & 9 & 16 & 25 & 36 & 49 & 64 & 81 & 100 \\
\hline
\end{tabular}

\begin{tabular}{|c|c|}
\hline $\begin{array}{l}\text { Reference interval based } \\
\text { on capsular contracture } \\
\text { score }\end{array}$ & $\begin{array}{c}\text { Capsular contracture grade according to the American } \\
\text { Society of Plastic Surgeons }\end{array}$ \\
\hline 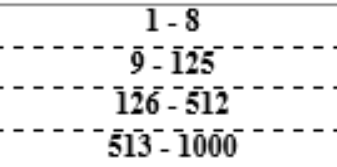 & $\begin{array}{c}\text { Grade } 1 \\
\text { Grade } 2 \\
\text { Grade } \overline{3} \\
\text { Grade } 4\end{array}$ \\
\hline
\end{tabular}

Table 2

CAPSULAR CONTRACTURE GRADE DEPENDING ON THE PROPOSED CAPSULAR CONTRACTURE PFD SCORE

\section{Results and discussions}

The results of the research indicate that capsular contracture had $10.67 \%$ incidence rate in the studied group. Regarding demographics, the average age of the patients was 51.15 years and $81.48 \%$ of the patients came from urban areas. Most of the patients have undergone breast augmentation for cosmetic purposes, while $22.22 \%$ have benefited from breast reconstruction after mastectomy. The specialized literature presents incouraging results related to the reduction of the capsular contracture rate through atraumatrical manipulation when the silicone prosthesis is inserted, as well as by using the no touch technique which involves inserting the implant using the funnel system. The gathered data shows that by using this technique the capsular contracture rate is 1.3\% compared to approximately $10 \%$ related to patients that received the classic surgical approach [28]. Therefore, by comparing the results of the current research with the findings from the specialized literature, a significant improvement in postoperative outcomes [29] can be achieved by modifying the implant introduction technique.

The average time interval between the surgical intervention and the consult was 6.87 years, the patients showing up on average almost 2 years after the occurence of the first symptoms (table 3). Using the proposed capsular contracture PFD scoring system, the average capsular contracture grade was 3.04. By analyzing the relation between the capsular contracture grade and the time interval between the initial surgery and the occurence of the symptoms, the results indicated a 95\% confidence level ( $p=0.025, p<0.05$ ). Regarding the patients' symptoms, the highest average score was related to breast pain, 6 of the patients grading the pain level with the maximum score.

In order to determine the possible causes related to the occurence of the capsular contracture, the study has focused on 4 main risk factors that may lead to this condition: postoperative complications, autoimmune disorders, radiation therapy in the medical history of the patients and whether the patient is a smoker or not. The results of the study show that $77.78 \%$ of the patients had atleast one of the risk factors, in the group of study being identified a total of 30 risk factors from maximum value of 108 (fig. 1). The most significant factor was the occurence of complications after the surgery (40.74\%). All the patients that have undergone breast reconstruction had had radiation therapy after mastectomy.

One of the most interesting cases was related to a 49 years old patient with grade 4 capsular contracture that came in for surgical consult 11 years after having undergone breast reconstruction with latissimus dorsi (LD) flap associated with breast implant (fig. 2).

As shown in the 11-year photo of the breast reconstruction, the contralateral breast has gone through the classic stages of the natural process of breast ptosis, unlike the reconstructed breast which, through the accentuated fibrosis processes, was anchored to the chest, losing its mobility and natural appearance. The comparative analysis of images performed before and after the explantation of the breast implant emphasizes the impact of the capsular contracture on the aesthetic aspect of the mammary region.

From the analysis of the research results, the profile of the patients included in the study shows a predisposition to the delayed surgical evaluation, the therapeutic solution being the explantation in most of the cases. The relatively long interval from the insertion of the prosthesis until the onset of the symptomatology may be an argument in favor of remodeling the structure of the implant coating, involving the application of chemicals on the textured or microtextured surface of the breast implant, the gradual release of these substances being a possible solution for the inhibition of the biochemical mechanisms involved in the fibrosis process. 
Table 3

PATIENT DATA IN RELATION WITH CAPSULAR CONTRACTURE

\begin{tabular}{|c|c|c|c|c|c|c|c|c|}
\hline & \multicolumn{3}{|c|}{ Time interval (years) between: } & \multicolumn{3}{|c|}{ Symptoms } & \multirow[b]{2}{*}{ PFD score } & \multirow[b]{2}{*}{$\begin{array}{l}\text { Capsular } \\
\text { contrac- } \\
\text { ture grade }\end{array}$} \\
\hline Patient & $\begin{array}{l}\text { - breast } \\
\text { augmentation } \\
\text { and the } \\
\text { occurrence of } \\
\text { symptoms }\end{array}$ & $\begin{array}{c}\text { - breast } \\
\text { augmentation } \\
\text { and the surgical } \\
\text { consult }\end{array}$ & $\begin{array}{l}\text { - the occurrence } \\
\text { of the symptoms } \\
\text { and the surgical } \\
\text { consult }\end{array}$ & $\begin{array}{c}\text { Breast } \\
\text { pain }\end{array}$ & $\begin{array}{l}\text { Breast } \\
\text { firm- } \\
\text { ness }\end{array}$ & $\begin{array}{c}\text { Breast } \\
\text { defor- } \\
\text { mity }\end{array}$ & & \\
\hline$\frac{1}{2}$ & $---\frac{5}{7}-$ & $---\frac{6}{7}$ & -1 & $\frac{7}{9}$ & $\frac{7}{9}$ & $-\frac{6}{7}$ & $--\frac{294}{567}$ & $--\frac{3}{4}-$ \\
\hline 3 & & & & 8 & & & $4 \overline{8}$ & \\
\hline 4 & & & & 10 & & & $-6 \overline{4} \overline{0}$ & $--\overline{2}$ \\
\hline 5 & & & & 10 & & & $3 \overline{0}$ & 1 \\
\hline 6 & & & & 5 & & & $\overline{0}$ & $\overline{3}$ \\
\hline 7 & & 5 & & 10 & & 10 & $\overline{000} 0^{-}$ & $\overline{4}$ \\
\hline 8 & & & & 15 & & & $4 \overline{0}$ & $\overline{4}$ \\
\hline 9 & & & & & & & $80^{-}$ & $\overline{2}$ \\
\hline 10 & & & & & & & $\overline{8}$ & $\overline{3}$ \\
\hline 11 & & & & & & & -7 & $\overline{3}$ \\
\hline 12 & & & & & & & $1 \overline{6}$ & \\
\hline 13 & & & & 5 & & & $7 \overline{2} \overline{0}$ & $\overline{2}$ \\
\hline 14 & & & & 10 & & & $8 \overline{0} \overline{0}$ & $\overline{4}$ \\
\hline 15 & & & & & & & & \\
\hline 16 & & & & & & & & \\
\hline 17 & & & $0^{-}$ & & & & $\overline{45}$ & $\overline{2}$ \\
\hline 18 & & & $5 . \overline{5}$ & $\overline{8}$ & & & & \\
\hline 19 & & 5 & $\overline{2} . \overline{5}$ & $\overline{8}$ & & & & \\
\hline 20 & & .5 & & & & & & \\
\hline 21 & & & ${ }^{-}$ & $\overline{8}$ & $\overline{10}$ & $10^{-}$ & $\overline{5} \overline{0}$ & $\overline{4}$ \\
\hline 22 & & & & & & & & \\
\hline 23 & & & $1-$ & & & & & \\
\hline 24 & & & ${ }^{-}$ & $\overline{8}$ & $\overline{1} \overline{0}$ & & $\overline{6} \overline{4} \overline{0}$ & $\overline{4}$ \\
\hline 25 & & & $-\overline{2}$ & 8 & & & $\overline{44 \overline{8}}$ & $\overline{3}$ \\
\hline 26 & & & $0^{-}$ & & 76 & & & $-\overline{3}$ \\
\hline 27 & & $\overline{-}$ & & & & & $\bar{E}$ & \\
\hline $\begin{array}{c}\text { Average } \\
\text { value }\end{array}$ & 4.93 & 6.87 & 1.94 & 7.30 & 6.74 & 6.89 & 425.44 & 3.04 \\
\hline
\end{tabular}

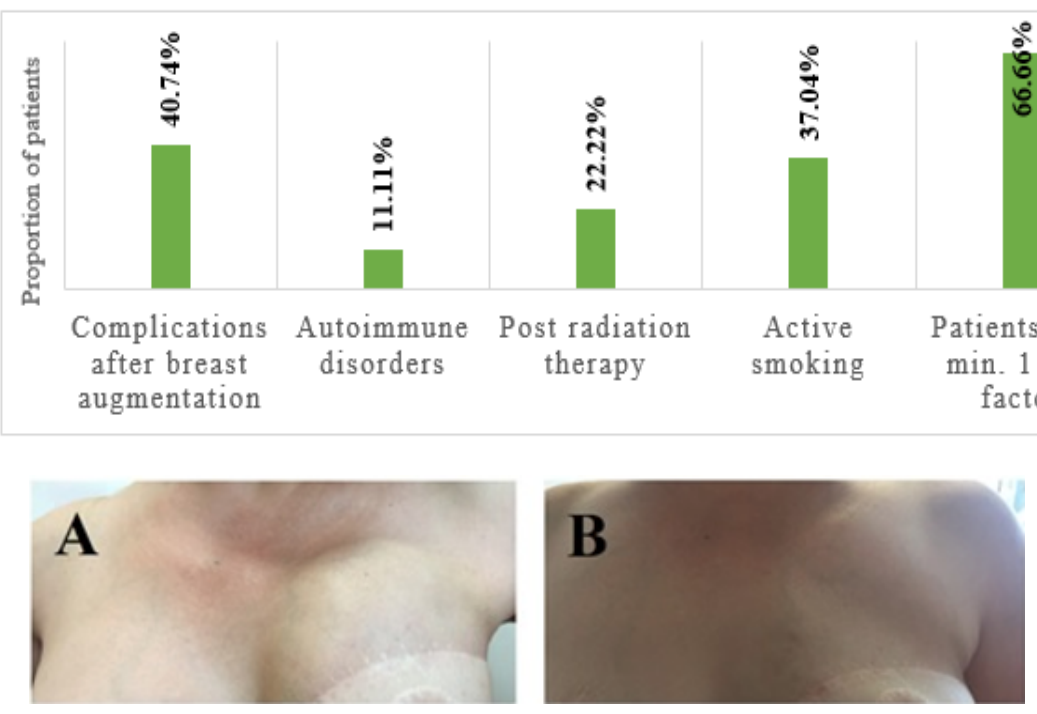

Fig. 2 Capsular contracture 11 years after breast reconstruction with LD flap associated with breast implant - Preoperative aspect $(A)$ and postoperative aspect (B)

Fig. 1 Proportion of patients in relation with the risk factors associated with capsular contracture

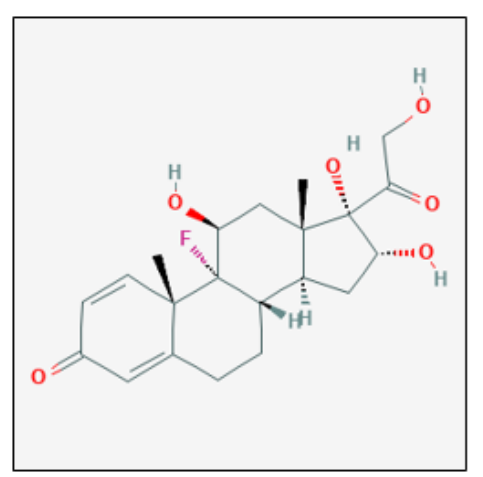

Fig. 3 Triamcinolone [31]
In this respect, the literature offers extensive documentation for the understanding of the interaction between the chemical substances applied to the surface of the implants and the capsular fibrosis mechanism. The the coating of the textured implants has the ability to be associated with the application of chemicals with inhibitory properties agaist the fibrosis process. In this regard triamcinolone $\left(\mathrm{C}_{21} \mathrm{H}_{27} \mathrm{FO}_{6}\right)$ (fig. 3) was used for the ability to inhibit the immune response by reducing TNF- $\alpha$ and
IL-1 $\beta$ expression, as well as reducing chemotaxis for polymorphonuclear cells and monocytes [30].

However, the adverse effects associated with the longterm administration of glucocorticoids reduce the enthusiasm related to this technique that modifies the surface of the implants.

Tranilast $\left(\mathrm{C}_{18} \mathrm{H}_{17} \mathrm{NO}_{5}\right.$ ) (fig. 4) is also a substance whose properties have shown to be useful in reducing the intensity of the fibrosis process [32]. By inhibiting TGF- $\beta$ secretion, 
this substance reduces the synthesis of collagen, thereby contributing to reducing the incidence of the previously described complications.

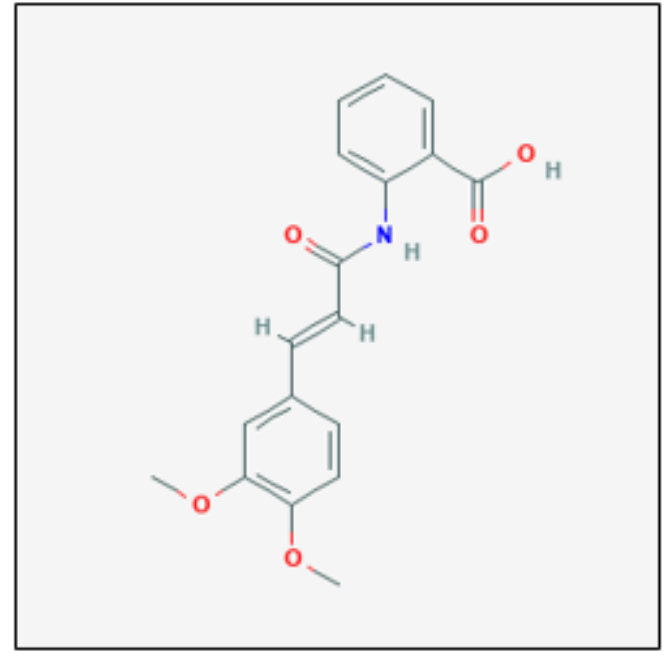

Fig. 4 Tranilast [33]

Specialized literature abounds with encouraging materials related to reducing the capsular contracture rate by applying different chemicals at the level of the implant coating. Montelukast $\left(\mathrm{C}_{35} \mathrm{H}_{36} \mathrm{CINO}_{3} \mathrm{~S}\right)$ (fig. 5) used for its properties that inhibit leukotriene has proven to be useful in reducing TGF- $\beta$ and myofibroblasts, but has not exerted any effect on macrophages [34].

Another product that offers encouraging results is zafirlukast $\left(\mathrm{C}_{31} \mathrm{H}_{33} \mathrm{~N}_{3} \mathrm{O}_{6} \mathrm{~S}\right)$ (fig. 6), which, by inhibiting eosinophils, appears to provide results in reducing the capsular contracture rate [35].

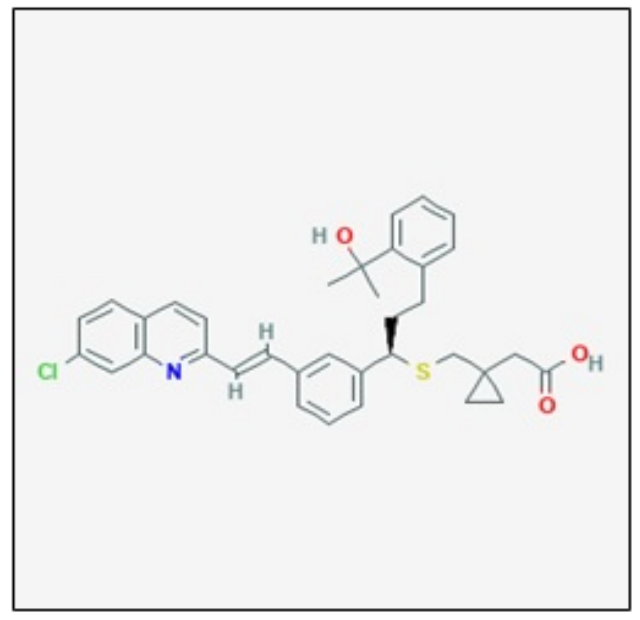

Fig. 5 Montelukast [36]

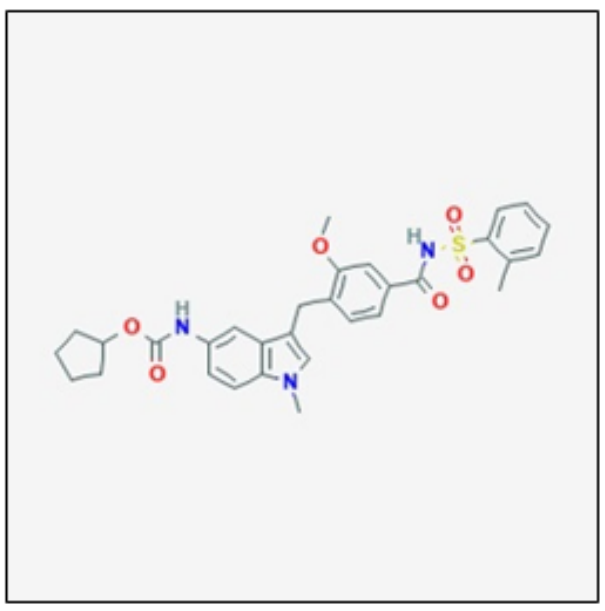

Fig. 6 Zafirlukast [37]
Without a doubt there is multitude of substances that, through their characteristic chemical properties, appear to offer benefits in terms of reducing inflammatory response and local fibrosis. However, chemical processes need to be analyzed in the actual clinical context, requiring additional large-scale and long-term studies in order to provide objective information on the effects of applying different chemicals to the surface of textured or microtextured implants.

\section{Conclusions}

Regardless of the objective of surgery, both in the case of elective breast augmentation and post-mastectomy reconstruction, the capsular contracture is a rare complication, which in most cases requires explanation. The chemical modification of the implant coating appears to be a feasible solution for the modulation of the immune response responsible for the appearance of the capsular contracture, yet further studies are needed in order to confirm this.

Centralizing information using the proposed PFD score can be a way of objectively reporting at institutional level, while creating the premise of multicentre comparative studies based on the same scoring system.

\section{References}

1.*** AMERICAN SOCIETY OF PLASTIC SURGEONS, 2019, p. 1, https:/ /www. plasticsurgery.org/documents/News/Statistics/2018/plasticsurgery-statistics-report-2018.pdf.

2.BEJ INARIU, C.G., MARINESCU, S.A., ENESCU, M.D., Modern Medicine, 26, no. 1, 2019, p. 17.

3.FILIP, C.I., BERBECE, S., RADUCU, L., FLORESCU, I.P., ARDELEANU, V., JECAN, C.R., Mat. Plast, 54, no. 3, 2017, p. 414.

4.***U.S. FOOD AND DRUG ADMINISTRATION, 2019, https:// www.fda.gov/ MedicalDevices/ProductsandMedicalProcedures/ ImplantsandProsthetics/Breastlmplants/ucm258564.htm.

5.MARINESCU S.A, BEJ INARIU C.G., GIUGLEA C., Mat. Plast., 56, no. 1, 2019, p.229.

6.MAXWELL G.P., GABRIEL A., Gland Surg., 6, no. 2, 2017, p. 148, doi: 10.21037/gs.2016.11.09.

7.KIM B.H., PARK M., PARK H.J., LEE S.H., CHOI S.Y., PARK C.G., HAN S.M., HEO C.Y., CHOY Y.B., Acta Biomater, 51, 2017, p. 209.

8.LEBERFINGER A.N., BEHAR B.) ., WILLIAMS N.C., RAKSZAWSKI K.L., POTOCHNY J.D., MACKAY D.R., RAVNIC D.J ., JAMA surgery, 152, nr. 12, 2017, p. 1161.

9.SFORZA M., ZACCHEDDU R., ALLERUZZO A., SENO A., MILETO D., PAGANELLI A, SULAIMAN H., PAYNE M., MAUROVICH-HORVAT L., Aesthet Surg J., 38, nr. 2, 2017, p.62.

10.CAPPELLANO G., PLONER C., LOBENWEIN S., SOPPER S., HOERTNAGL P., MAYERL C., WICK N., PIERER G., WICK G., WOLFRAM D., PLoS One, 13, no. 2, 2018, doi: 10.1371/journal.pone.0192108.

11.MALAHIAS M., JORDAN D., HUGHES L., HINDOCHA S., JUMA A., International Journal of Surgery Open, 3, 2016, p. 1.

12.HEADON H., KASEM A., MOKBEL K., Archives of plastic surgery, 42, no. 5, 2015, p. 532.

13.WICK G., BACKOVIC A., RABENSTEINER E., PLANK N., SCHWENTNER C., SGONC R., Trends Immunol, 31, no. 3, 2010, p. 110. 14.BEJ INARIU, C.G., MARINESCU, S., GIUGLEA C., Romanian Medical Journal, LXVI(1), 2019, pp. 33.

15.NITULESCU, G.M., IANCU, G., NITULESCU, G., IANCU, R.C., BOGDANICI, C., VASILE, D., Rev.Chim.(Bucharest), 68, no. 4, 2017, p. 754.

16.ROLFE B., MOONEY J., ZHANG B., JAHNKE S., LE S.J ., CHAU Y.Q., HUANG Q., WANG H., CAMPBELL, G., CAMPBELL, J., InTech, 2011, p. 551.

17.KLOPFLEISCH R., JUNG F., J Biomed Mater Res A, 105, no. 3, 2017, p. 927.

18.ZHANG L., CAO Z., BAI T, CARR L., ELLA-MENYE J.R., IRVIN C, RATNER B.D., JIANG S., Nat Biotechnol, 31, no. 6, 2013, p. 553. 
19.NICOLESCU, C., POP, A., MIHU, A., PILAT, L., BEDREAG, 0. NICOLESCU, L., Rev. Chim. (Bucharest), 69, no. 7, 2018, p. 1830. 20.CLARK R.A.F., Springer Science \& Business Media, 2013, p. 314. 21.NAKAMURA I., ZAKHARIA K., BANINI B.A., MIKHAIL D.S., KIM T.H., YANG J .D., MOSER C.D., SHALEH H.M., THORNBURGH S.R., WALTERS I.,ROBERTS L.R., PLoS One, 9(4), 2014, doi: 10.1371/journal. pone .0092273 .

22.MIOC, M., AVRAM, S., BERCEAN, V., BALAN PORCARASU, M., SOICA, C., SUSAN, R., KURUNCZI, L., Rev.Chim. (Bucharest), 68, no. 4, 2017, p. 745.

23.KREUGER J., PHILLIPSON M., Nat Rev Drug Discov,15, no. 2, 2016, p. 125.

24.SHEIKH Z., BROOKS P.J., BARZILAY O., FINE N., GLOGAUER M., 8, no. 9,2015, p. 5671.

25.MARINESCU, S.A., BEJINARIU, C.G., BADEANA, A., TANASESCUCIUVICA, S., Rev. Chim.(Bucharest), 70, no.4, 2019, p. 1234

26.STEVENS W.G., NAHABEDIAN M.Y., CALOBRACE M.B., HARRINGTON J.L., CAPIZZI P.J ., COHEN R., D'INCELLI R.C., BACKSTRAND M., Plast Reconstr Surg, 132, nr. 5, 2013, p. 1115.

27.TEHRANI K., American Society of Plastic Surgeons, 2018, https:// www.plasticsurgery.org/news/blog/what-is-capsular-contracture-andhow-can-it-be-treated.

28.NEWMAN A. N., DAVISON S.P., Plastic and Reconstructive Surgery Global Open, 6, no. 6, 2018, doi: 10.1097/GOX.00000000000001834.
29.BEJ INARIU, C.G., APOSTOLESCU, I., MARINESCU, S., Romanian J ournal of Medical Practice, 14, no. 1, 2019, p. 48.

30.CAIN D.W., CIDLOWSKI J.A., Nat Rev Immunol,17, nr. 4, 2017, p. 233.

31.*** U.S. NATIONAL LIBRARY OF MEDICINE, Pubchem Database, 2019, https://pubchem.ncbi.nlm.nih.gov/compound/triamcinolone. 32.PRUD'HOMME G.J., Lab Investig, 87, no. 11, 2007, p.1077.

33.***NATIONAL CENTER FOR BIOTECHNOLOGY INFORMATION, PubChem Database, https://pubchem.ncbi.nlm.nih.gov/compound/ 5282230 .

34.SMITH T.L., SAUTTER N.B., Laryngoscope, 124, no. 8, 2014, pp. 1735.

35.MASTALERZ L., KUMIK J., Pol Arch Med Wewn, 120, no. 3, 2010, pp. 103.

36.***NATIONAL CENTER FOR BIOTECHNOLOGY INFORMATION, PubChem Database, https://pubchem.ncbi.nlm.nih.gov/compound/ 5281040.

37.***NATIONAL CENTER FOR BIOTECHNOLOGY INFORMATION. PubChem Database, https://pubchem.ncbi.nlm.nih.gov/compound/ 5717.

Manuscript received: 18.09 .2018 